\title{
On the role of germ cells in mammalian gonad development: quiet passengers or back-seat drivers?
}

\author{
Clarissa Rios-Rojas, Josephine Bowles and Peter Koopman \\ Institute for Molecular Bioscience, The University of Queensland, Brisbane, Queensland 4072, Australia \\ Correspondence should be addressed to P Koopman; Email: p.koopman@imb.uq.edu.au
}

\begin{abstract}
In addition to their role as endocrine organs, the gonads nurture and protect germ cells, and regulate the formation of gametes competent to convey the genome to the following generation. After sex determination, gonadal somatic cells use several known signalling pathways to direct germ cell development. However, the extent to which germ cells communicate back to the soma, the molecular signals they use to do so and the significance of any such signalling remain as open questions. Herein, we review findings arising from the study of gonadal development and function in the absence of germ cells in a range of organisms. Most published studies support the view that germ cells are unimportant for foetal gonadal development in mammals, but later become critical for stabilisation of gonadal function and somatic cell phenotype. However, the lack of consistency in the data, and clear differences between mammals and other vertebrates and invertebrates, suggests that the story may not be so simple and would benefit from more careful analysis using contemporary molecular, cell biology and imaging tools.

Reproduction (2015) 149 R181-R191
\end{abstract}

\section{Introduction}

In his book The Selfish Gene published in 1976, Richard Dawkins portrays the organism as a temporary vessel or 'survival machine' for genes (Dawkins 1976). Viewed in this way, it is the germ cells that represent the critical components of the machine, as they form the sperm and egg cells that carry the genetic information from one generation to the next. Irrespective of whether Dawkins' gene-centred view of evolution is valid, it is clear that the organism makes, regulates and nurtures its germ cells with great care, and employs various mechanisms to protect their DNA cargo from potential damage. These processes involve co-ordinated physical and molecular communication from the somatic cells of the gonads to the germ cells. The nature of this communication has been studied intensely and has started to become clear in the last decade (Ross \& Capel 2005, Bowles \& Koopman 2010).

Less clear is whether molecular signals also flow in the reverse direction. In the case of the ovary, studies on mice and other vertebrates where gonads have been depleted of germ cells have suggested that germ cells are required for maintaining tissue integrity in the postnatal period (Guigon \& Magre 2006). The stage at which the presence of germ cells becomes critical is not yet known, and the key signals coming from the germ cells have not been identified. For the testis, it is conventionally accepted that establishment and maintenance of tissue architecture are unaffected in the absence of germ cells (McLaren 1991, 1995), suggesting that no signals from germ cells are required.

This review focuses on the role of germ cell signalling during foetal gonadal development. We examine recent experimental analyses of gonadal development and maintenance in the absence of germ cells, in both males and females. This evidence comes mostly from studies on mice, and also involves representatives of several other taxa including fish, reptiles, anurans and insects. Our analysis of the published data exposes many instances of conflicting observations and leads us to conclude that current dogma deserves to be re-examined by a systematic approach using contemporary molecular, genetic and embryological tools.

\section{Sex determination and early gonad development}

In the mouse embryo, primordial germ cells (PGCs) arise from a group of pluripotent epiblast cells that cluster at the base of the allantois in the extraembryonic mesoderm at $\sim 7.25$ days post coitum (dpc) (Ginsburg et al. 1990, Lawson \& Hage 1994). Migrating PGCs colonise the embryonic gonads (the genital ridges) at $\sim 10 \mathrm{dpc}$, just as somatic sex determination is about to begin. At this stage, the genital ridges are morphologically and functionally identical between males and females. The supporting cell lineage has the potential to develop as either granulosa cells (in females) or Sertoli 
cells (in males), depending on the presence and expression of Sry (Koopman et al. 1991).

If present and functional, SRY triggers the upregulation of Sox9 and the specification of Sertoli cell precursors (Sekido \& Lovell-Badge 2008). SOX9 expression sets in train a cascade of transcriptional and signalling events that not only reinforce Sertoli cell fate but also influence the differentiation of other bipotential lineages and induces testis-specific organogenetic changes such as delineation of testis cords and interstitium, and vascularisation (for review, see Svingen \& Koopman (2013)). These signalling pathways involve secreted ligands such as fibroblast growth factor 9 (FGF9; Kim et al. 2006), prostaglandin D2 (PGD2; Wilhelm et al. 2005, Kim et al. 2006), anti-Müllerian hormone $(\mathrm{AMH}$; Behringer et al. 1994) and desert hedgehog (Behringer et al. 1994, Bitgood et al. 1996). As a result of this complex signalling network, the basic architecture of the testis is in place by $12.5 \mathrm{dpc}$.

In the XX embryo, absence of Sry results in the differentiation of the gonads into ovaries, marked by the development of supporting cells into pre-granulosa cells (McLaren 1991). This differentiation is known to involve key regulators such as forkhead box protein L2 (FOXL2), $\beta$-catenin, R-spondin 1 (RSPO1) and Wingless-type MMTV integration site family, member 4 (WNT4; Liu et al. 2010). Little histological organisation emerges during early ovarian development, and germ cells remain mixed with somatic cells until the formation of follicles, where a single oocyte is surrounded by granulosa cells and theca cells (Ungewitter \& Yao 2013). Compared with the testis, much less is known about the signalling environment present in the ovary and how the sex-specific differentiation of the different cell lineages is coordinated.

\section{Somatic signals dictate germ cell sex differentiation}

While gonadal somatic development is progressing, germ cells start to differentiate as either prospermatogonia in males or oocytes in females. In the mouse ovary, germ cells enter meiosis at $\sim 13.5 \mathrm{dpc}$ and arrest in prophase I before birth, remain in this suspended state until just before ovulation and finally complete meiosis at fertilisation. In contrast, germ cells in the mouse testis are arrested in G0/G1 of the cell cycle at $\sim 14.5 \mathrm{dpc}$, resuming mitosis immediately after birth and initiating meiosis later during puberty (McLaren 2003). Although entry into meiosis is normally considered a hallmark of oocyte differentiation, recent evidence has emerged that suggests the two processes are genetically separable (Dokshin et al. 2013).

In experimentally created $X X / X Y$ chimeras, all germ cells, whether $\mathrm{XX}$ or $\mathrm{XY}$, are able to enter meiosis when present in a foetal ovary, or to enter mitotic arrest when present in a foetal testis (Ford et al. 1975, Adams \& McLaren 2002). Thus, germ cell sex differentiation is dependent on signals from the surrounding environment rather than on the chromosomal sex of the germ cells themselves. Although the nature of the somatic signals regulating germ cell sex differentiation remained elusive for several decades, retinoic acid (RA) has emerged in recent years as the key driver of meiotic induction in the ovary (Bowles et al. 2006, Koubova et al. 2006, Bowles \& Koopman 2007, MacLean et al. 2007, Griswold et al. 2012). RSPO1, a regulator of the canonical WNT/ $\beta$-catenin signalling pathway, is secreted by somatic cells of the developing ovary and appears to influence germ cell proliferation, gene expression and entry into meiosis, based on analysis of the gonadal phenotype in Rspo1-knockout mice (Chassot et al. 2011).

In the foetal testis, FGF9 acts to antagonise RA, inhibit germ cell entry into meiosis (Bowles et al. 2010) and maintain expression of pluripotency-related genes such as Oct4 and Sox2 in testicular germ cells, evidently by activating the Nodal signalling pathway (Spiller et al. 2012). More recently, mutant mouse gonads lacking both L- and H-Pgds (L/H-Pgds knockout) showed increased numbers of germ cells due to increased proliferation and inhibition of mitotic arrest, altered transcription of germ cell genes and increased expression of pluripotency markers, perhaps by a combination of direct and indirect effects (Moniot et al. 2014).

Hence, a number of known somatic factors combine to direct meiotic entry, sex differentiation, proliferation and pluripotency of foetal germ cells, and it is possible that other such factors remain yet to be identified.

\section{Germ cell signalling to soma: studies of mammalian ovary development}

In contrast to the well-studied signalling from the somatic cells to the germ cells of the foetal gonads, little is known about how germ cells affect development of the soma. Since the 1950s, a variety of approaches have been used to deplete the gonads of germ cells and examine the consequences. Results from a number of these studies suggest a significant role for germ cells in the regulation and/or maintenance of ovarian development (Table 1).

Chemical depletion of PGCs can be achieved by the cytotoxic action of busulfan, a drug that destroys PGCs if administered at $11 \mathrm{dpc}$ in mice (Hemsworth \& Jackson 1963, Heller \& Jones 1964). The effect of absence of germ cells has also been evaluated in mouse models with naturally occurring mutations, such as the dominant white spotting (W) and Steel (SI) mutant strains. These mice have a defect in the migration of PGCs, leading to a greatly reduced number of germ cells colonising the genital ridges (Little \& Cloudman 1937, McCoshen \& McCallion 1975). More recent studies have made use of whole-body $\gamma$-irradiation of postnatal female rats (inducing death of most germ cells; Guigon et al. 2003), or growth differentiation factor 9 
Table 1 Key experiments investigating the effects of germ cell loss in the adult/late foetal/early foetal mammalian ovary.

\begin{tabular}{|c|c|c|c|c|c|}
\hline $\begin{array}{l}\text { Stage of germ } \\
\text { cell loss }\end{array}$ & Time of analysis & Experimental system & Analysis & Results & References \\
\hline \multirow[t]{7}{*}{ Adult } & $29-31 \mathrm{dpn}$ & $\begin{array}{l}\text { Rat follicle cell culture } \\
\text { with/without oocytes }\end{array}$ & Histology & $\begin{array}{l}\text { Luteinisation of granulosa } \\
\text { cells }\end{array}$ & $\begin{array}{l}\text { Nekola \& Nalbandov } \\
\text { (1971) }\end{array}$ \\
\hline & $22-26 \mathrm{dpn}$ & $\begin{array}{l}\text { Oocytectomised mouse } \\
\text { ovaries }\end{array}$ & Histology & $\begin{array}{l}\text { Increased production of } \\
\text { progesterone }\end{array}$ & $\begin{array}{l}\text { Vanderhyden et al. } \\
\text { (1993) and }\end{array}$ \\
\hline & & & & $\begin{array}{l}\text { Decrease in oestradiol } \\
\text { production }\end{array}$ & $\begin{array}{l}\text { Vanderhyden \& } \\
\text { Macdonald (1998) }\end{array}$ \\
\hline & 2.5-7 months & $\alpha \beta$ ERKO mice & $\begin{array}{l}\text { Histology, ImHC for SOX9, } \\
\text { AMH }\end{array}$ & Transdifferentiation & Couse et al. (1999) \\
\hline & $0-14 \mathrm{dpn}$ & $\mathrm{AMH}$ transgenic mice & Histology & Transdifferentiation & Behringer et al. (1990) \\
\hline & $5-12$ dpn & $\begin{array}{l}\text { Ovaries after irradiation } \\
\text { of oocytes }\end{array}$ & $\begin{array}{l}\text { Histology, ImHC and PCR for } \\
\text { FOXL2, AMH, SOX9, OSP }\end{array}$ & Transdifferentiation & Guigon et al. (2005) \\
\hline & 2 months & Gdf9Cre mice & $\begin{array}{l}\text { Histology, ImHC for FOXL2, } \\
\text { SOX9, HSD17B1, CST9 }\end{array}$ & No effect & Uhlenhaut et al. (2009) \\
\hline \multirow[t]{11}{*}{ Foetal } & Birth-28 days & $\begin{array}{l}W \text { mutants }\left(W^{v} W^{v}, W^{v}\right. \\
\text { and } W W)\end{array}$ & Histology & $\begin{array}{l}\text { Smaller ovaries, retardation } \\
\text { of follicle development } \\
\text { and increase in atretic } \\
\text { follicles }\end{array}$ & Coulombre (1954) \\
\hline & $\begin{array}{l}\text { Up to } 66 \text { days } \\
\text { after trans- } \\
\text { plantation }\end{array}$ & $\begin{array}{l}\text { Grafting of } 12 \mathrm{dpc} \text { foetal } \\
\text { ovaries in the kidneys } \\
\text { of adult male hosts }\end{array}$ & Histology & Transdifferentiation & $\begin{array}{l}\text { Taketo-Hosotani et al. } \\
\text { (1985) }\end{array}$ \\
\hline & & & & Production of testosterone & \\
\hline & 15 dpc-90 dpn & $K i t^{W v / W v}$ mice & EM & Non-developed ovaries & $\begin{array}{l}\text { Merchant-Larios \& } \\
\text { Centeno (1981) }\end{array}$ \\
\hline & & & & No folliculogenesis & \\
\hline & $\begin{array}{l}10 \text { days in } \\
\text { culture }\end{array}$ & $\begin{array}{l}\text { Exposure of } 14 \mathrm{dpc} \text { ovar- } \\
\text { ies to AMH in culture }\end{array}$ & Histology & Transdifferentiation & Vigier et al. (1987) \\
\hline & $\sim 13 \mathrm{dpc}$ & $\begin{array}{l}\text { Grafting of somatic cells } \\
\text { reaggregates in female } \\
\text { hosts }\end{array}$ & Histology & Transdifferentiation & Hashimoto et al. (1990) \\
\hline & $18.5 \mathrm{dpc}$ & $\begin{array}{l}\text { Busulfan-treated mice } \\
\quad(10.5-11.5 \mathrm{dpc})\end{array}$ & $\begin{array}{l}\text { ImHC for Laminin, PECAM } \\
\text { and GATA4 }\end{array}$ & No effect & Maatouk et al. (2012) \\
\hline & $14.5 \mathrm{dpc}$ & $K i t^{W v / W_{v}}$ mice & ImHC for FOXL2, SOX9, SCP3 & No effect & \\
\hline & 11 dpc-birth & $\begin{array}{l}\text { Busulfan-treated mice } \\
\quad(11 \mathrm{dpc})\end{array}$ & Histology & No effect & Merchant (1975) \\
\hline & $11-14 \mathrm{dpc}$ & $\mathrm{SI} / \mathrm{SL}^{\mathrm{d}}$ mice & Histology & $\begin{array}{l}\text { Non-developed ovaries } \\
\text { but no evidence of } \\
\text { transdifferentiation }\end{array}$ & McCoshen (1982) \\
\hline
\end{tabular}

ImHC, immunohistochemistry; EM, electron microscopy.

(Gdf9)-Cre;R26DTA mice, in which Gdf9 expression is activated at the primary follicular stage (just before birth) to drive germ cell-specific CRE production that activates diphtheria toxin, resulting in germ cell ablation (Uhlenhaut et al. 2009). The fate of the somatic population has also been evaluated by dissociating and reaggregating somatic cells (Hashimoto et al. 1990), then transplanting the resultant cell pellets into ovarian bursas of ovariectomised nude mice (Regenass et al. 1982), or by transplanting ovaries beneath the kidney capsule of adult male mice (Taketo-Hosotani et al. 1985). Results from these approaches are discussed in the following sections.

\section{Effects on establishment of ovarian cell phenotype}

A large body of work relates to ovaries from which germ cells were depleted from a very early stage, either before or during gonadal sex determination, chemically (by treatment with busulfan in rats or mice at $\sim 10.5 \mathrm{dpc}$ ) or genetically (in $\mathrm{W} / \mathrm{W}$ or $\mathrm{SI} / \mathrm{SL}^{\mathrm{d}}$ mutant mice germ cell colonisation of the gonad is hampered). McCoshen (1982) evaluated $S \mathrm{SI} / \mathrm{SL}^{\mathrm{d}}$ female mutants from 11 to $14 \mathrm{dpc}$ and found streak gonads with the appearance of condensed stromal tissue. Merchant-Larios \& Centeno (1981) analysed germ cell-free $W^{v}$ mutant mouse ovaries at later time points, from $15 \mathrm{dpc}$ to 90 days post natum (dpn), by electron microscopy and found that the formation of follicles was prevented, leading to the development of streak ovaries by $\sim 30 \mathrm{dpn}$. In addition, W/W mutant mice were studied histologically from birth to 28 days postnatal. At all ages examined, sterile ovaries were much smaller than normal, with a tendency for retardation of follicle development and the proportion of atretic follicles increased greatly from 7 to 28 days together (Coulombre 1954). Finally, it has been reported that somatic sex reversal observed in both $X Y(D O M)$ and B6-XXSxr mice is exacerbated by KitW-42J, an allele that prevents germ cells from reaching the gonads (Nagamine \& Carlisle 1996, Nagamine et al. 1998), suggesting that early foetal germ cells may provide signals that influence sex-determining pathways. 


\section{Effects on luteinisation}

Another somatic change affected by the presence or absence of germ cells is luteinisation, an essential process of the post-ovulatory follicle. During luteinisation, granulosa and theca cells are induced to develop into a corpus luteum by an ovulatory stimulus. The mechanisms underlying the regulation of this process have been mainly attributed to circulating hormones. However, luteinisation has been observed in cultures of rat follicular cells in which oocytes were removed by enzyme treatment and centrifugation, suggesting that oocytes secrete a factor or factors that prevent luteinisation (Nekola \& Nalbandov 1971). Oocyte degeneration was found to be highly correlated with luteinisation in studies on oestrogen-treated rats in which the majority of luteinised follicles contained a degenerating oocyte (Hubbard \& Erickson 1988). Both studies support the concept that the oocyte may be an ovarian regulator of luteinisation.

\section{Effects on somatic cell function}

Several lines of evidence have emerged that suggest that germ cells play a role in promoting differentiation of ovarian somatic cells and establishing or maintaining their function. Defective follicle maturation has been described in knockout mice lacking germ cell-derived factors such as GDF9, factor in the germline alpha, or bone morphogenetic protein 15 (Vanderhyden et al. 1992, Dong et al. 1996, Galloway et al. 2000, Soyal et al. 2000, Eppig et al. 2002). Moreover, culture of oocytectomised ovaries (from which oocytes were microsurgically removed) in an oocyte-conditioned medium showed that oocyte-derived factors regulate steroidogenesis in granulosa cells by inhibiting progesterone production and stimulating production of oestradiol $\left(E_{2}\right)$ (Vanderhyden et al. 1993, Vanderhyden \& Macdonald 1998); the germ cell-derived factor(s) responsible have not been identified.

\section{Effects on transdifferentiation}

A number of studies have reported on somatic transdifferentiation associated with degeneration of germ cells in foetal and adult ovaries. Ubiquitous overexpression of an $\mathrm{AMH}$ transgene using a metallothionein 1 promoter in XX mice results in ovaries containing few germ cells at birth and total loss of germ cells within a further 2 weeks. In these mice, the somatic population reorganises into structures that resemble seminiferous tubules when analysed histologically. Later in development, these structures degenerate and are undetectable in adult females (Behringer et al. 1990). Similarly, somatic cell transdifferentiation was observed in explanted rat ovaries exposed to purified bovine $\mathrm{AMH}$ at $14 \mathrm{dpc}$ and maintained in culture for 3-10 days
(Vigier et al. 1987). Treated ovaries showed degeneration of germ cells and formation of testis cord-like structures when cultured ex vivo up to 10 days.

Secondly, transdifferentiation was also observed in alpha-beta oestrogen receptor knockout mice ( $\alpha \beta E R K O)$ mice (Couse et al. 1999). Ovaries in these mice contained some areas with degenerated oocytes and other areas with no evidence of germ cells. The latter areas also contained somatic cells with a tripartite nucleolus, alignment with basal lamina and veil-like cytoplasmic processes, all characteristics of Sertoli cells. Immunohistochemical analysis demonstrated that these transdifferentiated somatic cells in $\alpha \beta E R K O$ mice express significantly increased levels of the Sertoli cell markers SOX9 and AMH (Couse et al. 1999).

In both cases, these data appear to provide support for the concept that loss of germ cells from an ovary triggers sex reversal of the somatic cell population. However, an alternative explanation is that the same stimulus that causes germ cell depletion (ectopic exposure to $\mathrm{AMH}$ and genetic loss of ERs) may directly cause somatic cell transdifferentiation or degeneration, without the effect resulting from the loss of germ cells per se.

When $12 \mathrm{dpc}$ ovaries (without mesonephroi) were grafted beneath the kidney capsules of adult male mice, the ovaries developed areas of testicular transdifferentiation accompanied by loss of germ cells (Taketo-Hosotani et al. 1985). These results were visualised under light and electron microscopes: transplanted ovaries developed normally at first, but from the 11th day after transplantation, groups of Sertoli cells, pregranulosa cells and transitional cells (with intermediate characteristics between Sertoli and pregranulosa) were observed. Later, between 33 and 66 days after transplantation, a mixture of ovarian and testicular structures (seminiferous cords) was found to be present in most of the grafts. These grafts were able to produce testosterone after 3 days in the culture, indicating that the development of steroidogenic Leydig cells had been achieved together with Sertoli differentiation. In contrast, similar grafts transplanted beneath the kidney capsule of an adult female mouse host contained only ovarian structures at all time points examined. As no oocytes were found in well-developed seminiferous tubules, it was assumed that transdifferentiation was an effect of germ cell loss, but it remains formally possible that the grafting itself influences somatic cell differentiation.

Other experiments provide arguably firmer evidence that loss of germ cells is the primary cause of ovarian transdifferentiation. Dissociated/reconstituted $12.5 \mathrm{dpc}$ mouse gonadal somatic cell pellets were analysed after grafting into ovarian bursas of ovariectomised female nude mice. Unlike ovarian somatic/germ cell aggregate controls, ovarian somatic cell aggregates devoid of germ cells did not form follicles, but rather transdifferentiated into Sertoli-like cells, suggesting that ovarian development requires the presence of germ cells (Hashimoto et al. 1990). 
In addition, whole-body $\gamma$-irradiation of female rats at $5 \mathrm{dpn}$ was used to kill most germ cells, leading to somatic transdifferentiation of some areas in the irradiated ovaries. Histological analyses showed that, at $\sim 12 \mathrm{dpn}$, treated ovaries contained oocyte-depleted follicles that survived and proliferated but acquired a Sertoli-like phenotype including an elongated cytoplasm, polarised nuclear localisation towards the basal lamina and a distinct morphology of the rough endoplasmic reticulum. Further characterisation of molecular markers expressed by the follicular cells revealed continued expression of the granulosa cell marker FOXL2 but not the Sertoli cell marker SOX9. Curiously, the Sertoli cell marker AMH and the bloodtestis barrier marker claudin 11 (CLDN11 or OSP) were also detected in the transdifferentiated areas (Guigon et al. 2005). These experiments support the view that signalling from germ cells is required for somatic integrity of the developing ovary, at least postnatally.

\section{Conflicting data: evidence that germ cells are not required for ovarian development}

In contrast to the findings outlined earlier, a body of evidence exists that supports the conclusion that germ cells play no role in ovarian development or maintenance. When busulfan was used to ablate germ cells at $11 \mathrm{dpc}$ in rats, high-resolution light and electron microscopic studies of undifferentiated gonads and ovaries analysed daily from $11 \mathrm{dpc}$ to birth showed no alteration in the morphology of somatic cells in the ovaries (Merchant 1975). More recent experiments using mice (Maatouk et al. 2012), where germ cells were ablated by the injection of busulfan at 10.5-11.5 dpc, also showed normal formation of the female gonads and proper maintenance of the different cell lineages when evaluated by immunofluorescence. At $14.5 \mathrm{dpc}$, granulosa cell markers FOXL2 and GATA4 were established normally in all ovarian somatic cells, and deposition of laminin was similar between control and treated ovaries. Similar results were observed at $18.5 \mathrm{dpc}$, with normal expression of FOXL2 and PECAM (a marker for vascular endothelial cells). In addition, sex reversal was not observed, as ectopic SOX9 expression was not detected in treated ovaries. Hence, both studies showed that busulfan-treated ovaries were unaffected by the absence of germ cells at the analysed time points. It remains possible to argue that germ cells do play a crucial role, but that the few germ cells remaining after busulfan treatment may be enough to direct normal differentiation of the ovary, although this seems unlikely.

Recent results even suggest that the presence of germ cells is not required postnatally for the maintenance of the ovarian soma. In a study on 8-week-old Gdf9-Cre;R26DTA mice, in which germ cells are selectively killed by transgenic expression of diphtheria toxin, ovaries showed no morphological evidence of transdifferentiation, no loss of the ovarian marker FOXL2 and no ectopic expression of the testicular Sertoli cell marker SOX9 (Uhlenhaut et al. 2009).

\section{Germ cell signalling to soma: studies of mammalian testis development}

\section{Effects on adult testis phenotype and function}

Several studies have established that active bidirectional communication occurs between spermatids and Sertoli cells in adult testes (Table 2). Some studies, where rats were treated with methoxyacetic acid (MAA), irradiation or busulfan for depletion of spermatocytes, revealed that spermatids can regulate Sertoli cell-specific factors such as cyclic protein 2 (CP2), sulphated glycoprotein 2 and interleukin 1 alpha (IL1 $\alpha$ ) (Maguire et al. 1993, McKinnell \& Sharpe 1997, Jonsson et al. 1999). Another study showed that tumour necrosis factor alpha, a secretory product of round spermatids, induces endogenous androgen receptor expression in primary cultures of Sertoli cells (Delfino et al. 2003). Further, factors secreted by pachytene spermatocytes were found to modulate the expression of a potential serotonin receptor mRNA and a second novel mRNA in Sertoli cells (Syed et al. 1999). Germ cell-conditioned medium was found to regulate $E_{2}$ and androgen-binding protein secretion by immature rat Sertoli cells (Le Magueresse \& Jegou 1986). Finally, busulfan treatment of adult mice resulted in increased expression of nine different genes encoding Sertoli cell markers and decreased expression of two others (O'Shaughnessy et al. 2008). It is worth noting, however, that busulfan acts on all proliferative cells, hence it is possible that the observed effects on somatic cells is due to general toxicity.

\section{Effects on foetal testis development}

In contrast to what happens in adults, no evidence has emerged that germ cells influence early testis development in the fetus (Table 2). Early histochemical and histological studies in male gonads of fetuses carrying an $\mathrm{Sl} / \mathrm{SL}^{\mathrm{d}}$ mutation showed normal development of the testes between 11 and $14 \mathrm{dpc}$. Mutant testes displayed well-developed seminiferous tubules populated by Sertoli cells (resembling tubules in 'Sertoli cell only' syndrome; McCoshen 1982). Other studies have demonstrated that somatic cells purified from dissociated $12.5 \mathrm{dpc}$ gonads and reaggregated and transplanted into ovarian bursas for 1 month could develop into testes even without the contribution of germ cells. Aggregates developed normal testis cords formed by differentiated Sertoli cells, Leydig cells and tunica albuginea (the connective tissue covering the testes; Hashimoto et al. 1990). Further, ultrastructural examination of $W^{v}$ mouse gonads revealed normal maturation of Sertoli cells postnatally, based on the observations of tripartite 
Table 2 Key experiments investigating the effects of germ cell loss in the adult/foetal mammalian testis.

\begin{tabular}{|c|c|c|c|c|c|}
\hline $\begin{array}{l}\text { Stage of germ } \\
\text { cell loss }\end{array}$ & $\begin{array}{l}\text { Time of } \\
\text { analysis }\end{array}$ & Experimental system & Analysis & Results & References \\
\hline \multirow[t]{3}{*}{ Adult } & Adults & Busulfan-treated mice & $\begin{array}{l}\text { PCR of Sertoli markers, } \\
\text { Leydig markers and } \\
\text { other somatic genes }\end{array}$ & $\begin{array}{l}\text { Increased expression: Cst9, } \\
\text { Shbg, Wnt5a, Clu, Il1a, } \\
\text { Cldn11, Cys12, Testin } \\
\text { and Amh } \\
\text { Decreased expression: } \\
\text { Spata2 and Sympk } \\
\text { Decreased expression: Pdgfa } \\
\text { No changes: Lhr, Star, Hsd3b6, } \\
\text { Cyp17a1 and Cyp11a1 } \\
\text { Increased expression: Bdegf36 } \\
\text { and Gata4 } \\
\text { Decreased expression: Dax1 }\end{array}$ & $\begin{array}{l}\text { O'Shaughnessy et al. } \\
\text { (2008) }\end{array}$ \\
\hline & Adults & $\begin{array}{l}\text { Post-natal germ cell } \\
\text { depletion by busulfan } \\
\text { treatment } \\
\text { Prenatal germ cell } \\
\text { depletion by foetal } \\
\text { irradiation }\end{array}$ & $\begin{array}{l}\text { In situ hybridisation, } \\
\text { ImHC and PCR }\end{array}$ & $\begin{array}{l}\text { Expression of IL } 1 \alpha \text { mRNA is } \\
\text { dependent upon interaction } \\
\text { with germ cells }\end{array}$ & Jonsson et al. (1999) \\
\hline & Adults & $\begin{array}{l}\text { Depletion of spermato- } \\
\text { cytes by administration } \\
\text { of MAA }\end{array}$ & $\begin{array}{l}\text { Northern blot } \\
\text { Histology }\end{array}$ & Decreased expression of CP2 & $\begin{array}{l}\text { Maguire et al. (1993) and } \\
\text { McKinnell \& Sharpe } \\
\text { (1997) }\end{array}$ \\
\hline \multirow[t]{3}{*}{ Foetal } & $\sim 13 \mathrm{dpc}$ & $\begin{array}{l}\text { Grafting of somatic cells } \\
\text { reaggregates in female } \\
\text { hosts }\end{array}$ & Histology & No effect & Hashimoto et al. (1990) \\
\hline & $\begin{array}{l}\text { Up to } 39 \text { days } \\
\text { post-natal }\end{array}$ & $K i t^{W v / W v}$ mice & EM & No effect & Handel \& Eppig (1979) \\
\hline & $11-14 \mathrm{dpc}$ & $\mathrm{Sl} / \mathrm{SL}^{\mathrm{d}}$ mice & Histology & No effect & McCoshen (1982) \\
\hline
\end{tabular}

ImHC, immunohistochemistry; EM, electron microscopy; MAA, methoxyacetic.

nucleolus, Sertoli cell junctions and presence of mitochondria (Handel \& Eppig 1979). Together, these results have now led to the universal view that germ cell signalling is not important during mammalian foetal testis development.

\section{Germ cell loss in other taxa}

The importance of germ cells to foetal gonad development has been clearly established in non-mammalian taxa (Fig. 1), as discussed in the following sections.

\section{Fish, reptiles and anurans}

Zebrafish provide an experimentally tractable model in which to examine the role of germ cells. In this species, loss of function of Dead-end, a gene required for PGC migration and survival, by morpholino oligonucleotide knockdown results in loss of germ cells (Weidinger et al. 2003). Germ cells can also be ablated using the Kid/Kis system, in which PGCs are eliminated by the toxin Kid, whereas somatic cells are protected by an antidote, Kis (de la Cueva-Mendez et al. 2003).

One study found that after treatment of zebrafish embryos by both means (use of morpholino and toxin), all offspring developed into adult males, evaluated by morphological and behavioural criteria. Gonads were present during development from 25 to 35 days post fertilisation (dpf), but later degenerated completely, so that from $90 \mathrm{dpf}$ onwards, no gonad-like structures were observed in experimental fish. These results suggest that germ cells play an essential role in reinforcing the female sex-determining pathway. Moreover, while germ cells are not needed for formation of gonads, they are important for differentiation and survival of gonad structures in both male and female adults (Slanchev et al. 2005).

Similar results were obtained by other workers using morpholino knockdown of Dead-end alone (Siegfried \& Nusslein-Volhard 2008) or analysing Piwi gene mutations (Houwing et al. 2007). In addition, use of metronidazole for oocyte ablation in 5-month-old zebrafish led to female-to-male sex reversal (if germline stem cells remain, adult females sex revert to spermproducing males; Houwing et al. 2007, Dranow et al. 2013). Moreover, a mutation in the Fanconi anemia complementation group L gene (fancl), which is expressed by germ cells, causes zebrafish to develop as male. Female-to-male sex reversal occurs due to an abnormal increase in programmed germ cell death that compromises oocyte survival: somatic cells do not maintain the female gene expression profile and become masculinised, developing into testes (Rodriguez-Mari et al. 2010).

Studies in medaka, where germ cells were depleted by a morpholino-mediated knockdown of cxcr4, a gene required for PGC migration, revealed a similar pattern, with deficiency of the germline leading to 


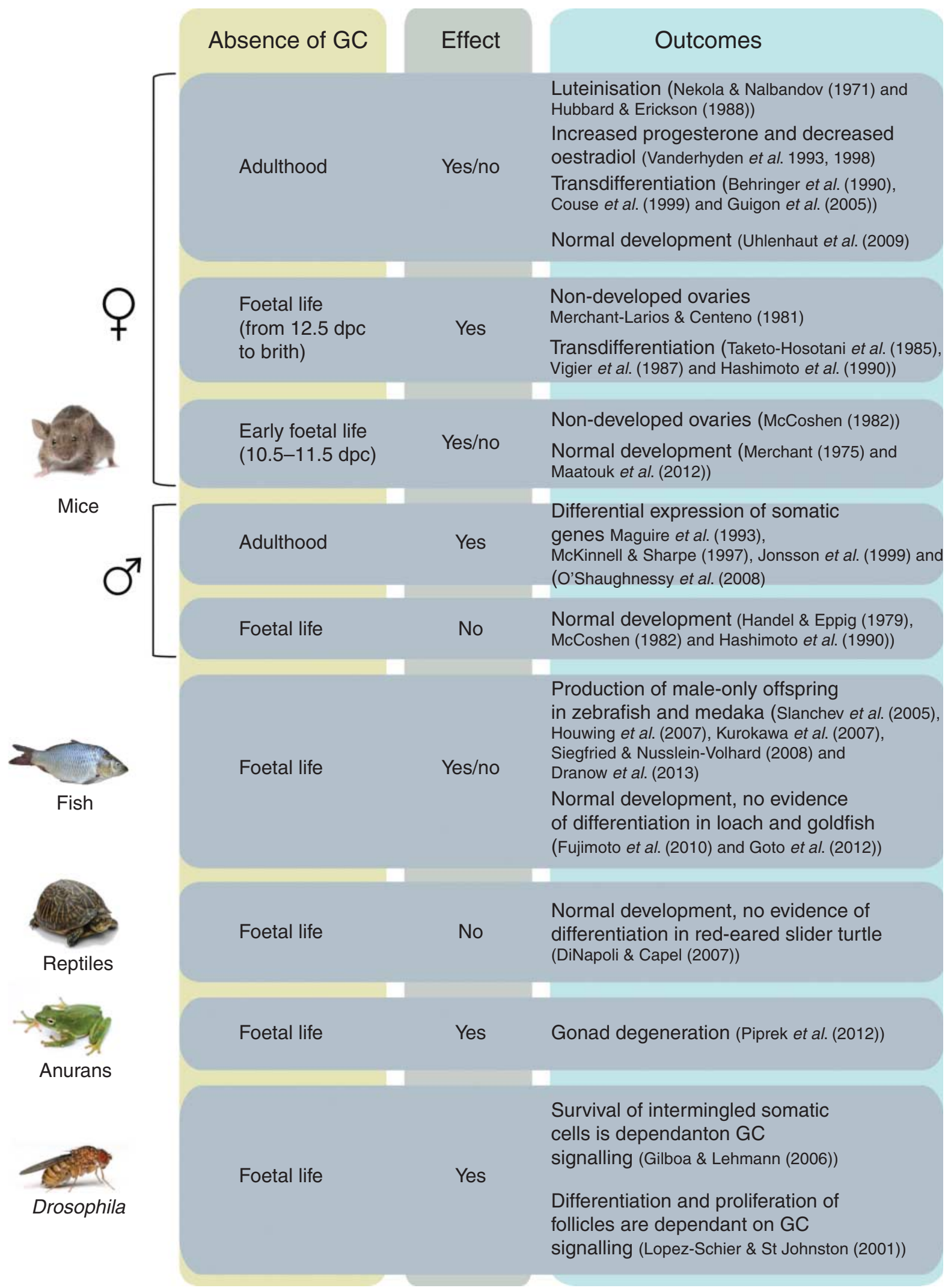

Figure 1 Importance of germ cells for sex development in different species. Comparative schema summarising the observed effects of absence of germ cells on sex development in mice, fish, reptiles, anurans and Drosophila. 'Yes/no effects' indicates conflicting data for the animal group analysed. 
female-to-male sex reversal in adults (Kurokawa et al. 2007). Moreover, in hotei medaka mutants, excessive germ cell proliferation causes male-to-female sex reversal in $50 \%$ of the offspring (Morinaga et al. 2007, Nakamura et al. 2012). Hence, it is well established that the germline is essential for proper somatic sex determination in these two species of fish.

However, this may not be true for all fish species. Germ cell-deficient gonads in the loach can develop into adult testes or ovaries that are normal morphologically and in terms of their gene expression (Fujimoto et al. 2010). In addition, a study on goldfish has demonstrated that ovary-like and testis-like structures are formed in the absence of germ cells and that a later transplantation of GFP-labelled germ cells can rescue both female and male fertility (Goto et al. 2012).

Germ cells have been ablated by busulfan in red-eared slider turtles, where morphological analysis of gonads, together with immunostaining for laminin, revealed that germ cells are not required for morphogenesis of either the testes or ovaries during foetal development (DiNapoli \& Capel 2007). Similar studies in four species of anurans showed histologically that germ cells are not necessary for the initial formation of genital ridges, but they are crucial for development of the ovaries and appear to be a key for the maintenance of gonadal structure (Piprek et al. 2012).

\section{Insects}

Evidence has been gathered through studies in Drosophila for the importance of germ cells in somatic gonadal development. Gilboa \& Lehmann (2006) demonstrated that proliferation of PGCs and the survival of intermingled cells (ICs: somatic cells in direct contact with germ cells) are connected by a feedback-loop mechanism, where epidermal growth factor receptor signalling plays a central role in a feedback loop coordinating IC survival and PGC proliferation. The authors propose that such a mechanism would ensure proper homoeostasis by coordinating the growth of gonads during the development of sex in Drosophila. Furthermore, activation of Notch on the somatic follicle triggered by Delta signalling coming from the germline has proven to control the proliferation and differentiation of somatic follicles during oogenesis in Drosophila (Lopez-Schier \& St Johnston 2001).

\section{Discussion and future prospects}

The general conclusion emerging from studies to date is that, in mammals, just as somatic cells of the gonads communicate to the germline using a variety of signals so too do the germ cells signal back to the somatic cells to regulate their differentiation and/or maintenance. However, our survey of the literature indicates that it is still not clear what role germ cells play in foetal development of either ovaries or testes, with many studies producing conflicting results or remaining otherwise open to interpretation. This situation is due in part to the fact that the relevant studies were conducted over a period of several decades, using different methods and markers, at different time points, involving different strains of mice and in some cases different rodent species. In some studies, limited time frames of evaluation did not allow for assessment of the longer-term effects of absence of germ cells in the gonads.

Furthermore, while the formation of the different cell lineages in the absence of germ cells in the female gonads has been extensively assessed by immunohistochemistry, similar rigour has not been applied to analyses of male gonads. The current view is that germ cells are important for foetal ovary development (a view not consistently supported by the body of data), and that germ cells are completely unimportant for foetal testis development. We suggest that it will be important to revisit these issues using contemporary tools, given the availability of new molecular markers and sophisticated quantitative gene and protein expression protocols, in addition to the development of advanced imaging and morphometric techniques. Moreover, the recent discovery that small molecules can inhibit specific chromatinassociated proteins expressed at different stages in spermatocytes and spermatids (Matzuk et al. 2012), offers new advanced tools for investigating germ cell function. Such studies will also benefit from the heightened awareness of the timing of key events such as the temporal sequence of gene expression, and regulation of cell cycle, genome methylation and entry into meiosis that has emerged in the last decade.

The impetus for such studies is provided by the clear body of evidence that germ cells are important for sex determination and/or somatic gonadal development in non-mammalian groups. In fish in particular, it is very clear that germ cells play an important role in maintaining the ovary phenotype, which in turn is essential for maintaining the female sex of the entire organism. This situation raises the possibility that signalling from germ cells is important in some taxa but either less so or not at all in others, perhaps depending on the type of sex-determining mechanism (for example, genetic or environmental) and degree of sex plasticity (for example, the ability of some fish species to change sex depending on social factors). If that is the case, some manifestations of these mechanisms may be present vestigially in mammals.

Finally, it is also interesting to note that signals from germ cells regulate the lifespan of Caenorhabditis elegans (Hsin \& Kenyon 1999), and that germ cell DNA damage activates a somatic stress resistance programme upon germ cells in the same species (Ermolaeva et al. 2013). While these phenomena and the mechanisms underpinning them are beyond the 
scope of this review, they clearly support the concept of germ cells as the source of signals to which somatic cells of the organism are responsive. Continued research into the signals emanating from germ cells during foetal development will further our understanding in diverse areas including disorders of sex development, infertility, gonadal germ cell cancers and evolutionary biology.

\section{Declaration of interest}

The authors declare that there is no conflict of interest that could be perceived as prejudicing the impartiality of the review.

\section{Funding}

This research was supported by the National Health and Medical Research Council (NHMRC) of Australia. C Rios-Rojas received an International Postgraduate Research Scholarship from the University of Queensland (UQ), a UQ Centennial Scholarship and a UQ Advantage Grant. P Koopman is a Senior Principal Research Fellow of the NHMRC.

\section{References}

Adams IR \& McLaren A 2002 Sexually dimorphic development of mouse primordial germ cells: switching from oogenesis to spermatogenesis. Development 129 1155-1164.

Behringer RR, Cate RL, Froelick GJ, Palmiter RD \& Brinster RL 1990 Abnormal sexual development in transgenic mice chronically expressing Müllerian inhibiting substance. Nature 345 167-170. (doi:10.1038/ 345167a0)

Behringer RR, Finegold MJ \& Cate RL 1994 Müllerian-inhibiting substance function during mammalian sexual development. Cell 79 415-425. (doi:10.1016/0092-8674(94)90251-8)

Bitgood MJ, Shen L \& McMahon AP 1996 Sertoli cell signaling by Desert hedgehog regulates the male germline. Current Biology 6 298-304. (doi:10.1016/S0960-9822(02)00480-3)

Bowles J \& Koopman P 2007 Retinoic acid, meiosis and germ cell fate in mammals. Development 134 3401-3411. (doi:10.1242/dev.001107)

Bowles J \& Koopman P 2010 Sex determination in mammalian germ cells: extrinsic versus intrinsic factors. Reproduction 139 943-958. (doi:10.1530/REP-10-0075)

Bowles J, Knight D, Smith C, Wilhelm D, Richman J, Mamiya S, Yashiro K, Chawengsaksophak K, Wilson MJ, Rossant J et al. 2006 Retinoid signaling determines germ cell fate in mice. Science 312 596-600. (doi:10.1126/science.1125691)

Bowles J, Feng CW, Spiller C, Davidson TL, Jackson A \& Koopman P 2010 FGF9 suppresses meiosis and promotes male germ cell fate in mice. Developmental Cell 19 440-449. (doi:10.1016/j.devcel.2010.08.010)

Chassot AA, Gregoire EP, Lavery R, Taketo MM, de Rooij DG, Adams IR \& Chaboissier MC 2011 RSPO1/ $\beta$-catenin signaling pathway regulates oogonia differentiation and entry into meiosis in the mouse fetal ovary. PLOS ONE 6 e25641. (doi:10.1371/journal.pone.0025641)

Coulombre JL 1954 Analysis of the pleiotropism at the W-locus in the mouse. The effects of $W$ and $W v$ substitution upon postnatal development of germ cells. Journal of Zoology 126 277-295. (doi:10.1002/jez. 1401260207)

Couse JF, Hewitt SC, Bunch DO, Sar M, Walker VR, Davis BJ \& Korach KS 1999 Postnatal sex reversal of the ovaries in mice lacking estrogen receptors $\alpha$ and $\beta$. Science 286 2328-2331. (doi:10.1126/science.286. 5448.2328) de la Cueva-Mendez G, Mills AD, Clay-Farrace L, Diaz-Orejas R \& Laskey RA 2003 Regulatable killing of eukaryotic cells by the prokaryotic proteins Kid and Kis. EMBO Journal 22 246-251. (doi:10.1093/emboj/ cdg026)

Dawkins R 1976 In The Selfish Gene. Oxford: Oxford University Press.

Delfino FJ, Boustead JN, Fix C \& Walker WH 2003 NF- $\kappa B$ and TNF- $\alpha$ stimulate androgen receptor expression in Sertoli cells. Molecular and Cellular Endocrinology 201 1-12. (doi:10.1016/S0303-7207 (03)00005-4)

DiNapoli L \& Capel B 2007 Germ cell depletion does not alter the morphogenesis of the fetal testis or ovary in the red-eared slider turtle (Trachemys scripta). Journal of Experimental Zoology. Part B, Molecular and Developmental Evolution 308 236-241. (doi:10.1002/ jez.b.21136)

Dokshin GA, Baltus AE, Eppig JJ \& Page DC 2013 Oocyte differentiation is genetically dissociable from meiosis in mice. Nature Genetics 45 877-883. (doi:10.1038/ng.2672)

Dong J, Albertini DF, Nishimori K, Kumar TR, Lu N \& Matzuk MM 1996 Growth differentiation factor-9 is required during early ovarian folliculogenesis. Nature 383 531-535. (doi:10.1038/383531a0)

Dranow DB, Tucker RP \& Draper BW 2013 Germ cells are required to maintain a stable sexual phenotype in adult zebrafish. Developmental Biology 376 43-50. (doi:10.1016/j.ydbio.2013.01.016)

Eppig JJ, Wigglesworth K \& Pendola FL 2002 The mammalian oocyte orchestrates the rate of ovarian follicular development. PNAS 99 2890-2894. (doi:10.1073/pnas.052658699)

Ermolaeva MA, Segref A, Dakhovnik A, Ou HL, Schneider J, Utermohlen O, Hoppe T \& Schumacher B 2013 DNA damage in germ cells induces an innate immune response that triggers systemic stress resistance. Nature 501 416-420. (doi:10.1038/nature12452)

Ford CE, Evans EP, Burtenshaw MD, Clegg HM, Tuffrey M \& Barnes RD 1975 A functional 'sex-reversed' oocyte in the mouse. Proceedings of the Royal Society of London. Series B, Containing Papers of a Biological Character. Royal Society 190 187-197. (doi:10.1098/rspb.1975.0086)

Fujimoto T, Nishimura T, Goto-Kazeto R, Kawakami Y, Yamaha E \& Arai K 2010 Sexual dimorphism of gonadal structure and gene expression in germ cell-deficient loach, a teleost fish. PNAS 107 17211-17216. (doi:10.1073/pnas.1007032107)

Galloway SM, McNatty KP, Cambridge LM, Laitinen MP, Juengel JL, Jokiranta TS, McLaren RJ, Luiro K, Dodds KG, Montgomery GW et al. 2000 Mutations in an oocyte-derived growth factor gene (BMP15) cause increased ovulation rate and infertility in a dosage-sensitive manner. Nature Genetics 25 279-283. (doi:10.1038/77033)

Gilboa L \& Lehmann R 2006 Soma-germline interactions coordinate homeostasis and growth in the Drosophila gonad. Nature 443 97-100. (doi:10.1038/nature05068)

Ginsburg M, Snow MH \& McLaren A 1990 Primordial germ cells in the mouse embryo during gastrulation. Development 110 521-528.

Goto R, Saito T, Takeda T, Fujimoto T, Takagi M, Arai K \& Yamaha E 2012 Germ cells are not the primary factor for sexual fate determination in goldfish. Developmental Biology 370 98-109. (doi:10.1016/j.ydbio.2012.07.010)

Griswold MD, Hogarth CA, Bowles J \& Koopman P 2012 Initiating meiosis: the case for retinoic acid. Biology of Reproduction 86 35. (doi:10.1095/ biolreprod.111.096610)

Guigon CJ \& Magre S 2006 Contribution of germ cells to the differentiation and maturation of the ovary: insights from models of germ cell depletion. Biology of Reproduction 74 450-458. (doi:10.1095/biolreprod.105.047134)

Guigon CJ, Mazaud S, Forest MG, Brailly-Tabard S, Coudouel N \& Magre S 2003 Unaltered development of the initial follicular waves and normal pubertal onset in female rats after neonatal deletion of the follicular reserve. Endocrinology 144 3651-3662. (doi:10.1210/en.2003-0072)

Guigon CJ, Coudouel N, Mazaud-Guittot S, Forest MG \& Magre S 2005 Follicular cells acquire Sertoli cell characteristics after oocyte loss. Endocrinology 146 2992-3004. (doi:10.1210/en.2005-0045)

Handel MA \& Eppig JJ 1979 Sertoli cell differentiation in the testes of mice genetically deficient in germ cells. Biology of Reproduction 20 1031-1038. (doi:10.1095/biolreprod20.5.1031)

Hashimoto N, Kubokawa R, Yamazaki K, Noguchi M \& Kato Y 1990 Germ cell deficiency causes testis cord differentiation in reconstituted mouse fetal ovaries. Journal of Experimental Zoology 253 61-70. (doi:10.1002/ jez.1402530109) 
Heller RH \& Jones HW Jr 1964 Production of ovarian dysgenesis in the rat and human by busulphan. American Journal of Obstetrics and Gynecology 89 414-420.

Hemsworth BN \& Jackson H 1963 Effect of busulphan on the developing ovary in the rat. Journal of Reproduction and Fertility 6 229-233. (doi:10. 1530/jrf.0.0060229)

Houwing S, Kamminga LM, Berezikov E, Cronembold D, Girard A, van den Elst H, Filippov DV, Blaser H, Raz E, Moens CB et al. 2007 A role for Piwi and piRNAs in germ cell maintenance and transposon silencing in zebrafish. Cell 129 69-82. (doi:10.1016/j.cell.2007.03.026)

Hsin H \& Kenyon C 1999 Signals from the reproductive system regulate the lifespan of $C$. elegans. Nature 399 362-366. (doi:10.1038/20694)

Hubbard GM \& Erickson GF 1988 Luteinizing hormone-independent luteinization and ovulation in the hypophysectomized rat: a possible role for the oocyte? Biology of Reproduction 39 183-194. (doi:10.1095/ biolreprod39.1.183)

Jonsson CK, Zetterstrom RH, Holst M, Parvinen M \& Soder O 1999 Constitutive expression of interleukin- $1 \alpha$ messenger ribonucleic acid in rat Sertoli cells is dependent upon interaction with germ cells. Endocrinology 140 3755-3761.

Kim Y, Kobayashi A, Sekido R, DiNapoli L, Brennan J, Chaboissier MC, Poulat F, Behringer RR, Lovell-Badge R \& Capel B 2006 Fgf9 and Wnt4 act as antagonistic signals to regulate mammalian sex determination. PLoS Biology 4 e187. (doi:10.1371/journal.pbio.0040187)

Koopman P, Gubbay J, Vivian N, Goodfellow P \& Lovell-Badge R 1991 Male development of chromosomally female mice transgenic for Sry. Nature 351 117-121. (doi:10.1038/351117a0)

Koubova J, Menke DB, Zhou Q, Capel B, Griswold MD \& Page DC 2006 Retinoic acid regulates sex-specific timing of meiotic initiation in mice. PNAS 103 2474-2479. (doi:10.1073/pnas.0510813103)

Kurokawa H, Saito D, Nakamura S, Katoh-Fukui Y, Ohta K, Baba T, Morohashi K \& Tanaka M 2007 Germ cells are essential for sexual dimorphism in the medaka gonad. PNAS 104 16958-16963. (doi:10.1073/pnas.0609932104)

Lawson KA \& Hage WJ 1994 Clonal analysis of the origin of primordial germ cells in the mouse. Ciba Foundation Symposium 182 68-84 (discussion 84-91).

Le Magueresse B \& Jegou B 1986 Possible involvement of germ cells in the regulation of oestradiol- $17 \beta$ and $A B P$ secretion by immature rat Sertoli cells (in vitro studies). Biochemical and Biophysical Research Communications 141 861-869. (doi:10.1016/S0006-291X(86)80252-2)

Little CC \& Cloudman AM 1937 The occurrence of a dominant spotting mutation in the house mouse. PNAS 23 535-537. (doi:10.1073/pnas.23. 10.535)

Liu CF, Liu C \& Yao HH 2010 Building pathways for ovary organogenesis in the mouse embryo. Current Topics in Developmental Biology 90 263-290. (doi:10.1016/S0070-2153(10)90007-0)

Lopez-Schier H \& St Johnston D 2001 Delta signaling from the germ line controls the proliferation and differentiation of the somatic follicle cells during Drosophila oogenesis. Genes and Development 15 1393-1405. (doi:10.1101/gad.200901)

Maatouk DM, Mork L, Hinson A, Kobayashi A, McMahon AP \& Capel B 2012 Germ cells are not required to establish the female pathway in mouse fetal gonads. PLOS ONE 7 e47238. (doi:10.1371/journal.pone. 0047238)

MacLean G, Li H, Metzger D, Chambon P \& Petkovich M 2007 Apoptotic extinction of germ cells in testes of Cyp26b1 knockout mice. Endocrinology 148 4560-4567. (doi:10.1210/en.2007-0492)

Maguire SM, Millar MR, Sharpe RM \& Saunders PT 1993 Stage-dependent expression of mRNA for cyclic protein 2 during spermatogenesis is modulated by elongate spermatids. Molecular and Cellular Endocrinology 94 79-88. (doi:10.1016/0303-7207(93)90054-N)

Matzuk MM, McKeown MR, Filippakopoulos P, Li Q, Ma L, Agno JE, Lemieux ME, Picaud S, Yu RN, Qi J et al. 2012 Small-molecule inhibition of BRDT for male contraception. Cell 150 673-684. (doi:10.1016/j.cell. 2012.06.045)

McCoshen JA 1982 In vivo sex differentiation of congeneic germinal cell aplastic gonads. American Journal of Obstetrics and Gynecology 142 83-88.

McCoshen JA \& McCallion DJ 1975 A study of the primordial germ cells during their migratory phase in Steel mutant mice. Experientia 31 589-590. (doi:10.1007/BF01932475)
McKinnell C \& Sharpe RM 1997 Regulation of the secretion and synthesis of rat Sertoli cell SGP-1, SGP-2 and CP-2 by elongate spermatids. International Journal of Andrology 20 171-179.

McLaren A 1991 Development of the mammalian gonad: the fate of the supporting cell lineage. BioEssays: News and Reviews in Molecular, Cellular and Developmental Biology 13 151-156. (doi:10.1002/bies. 950130402)

McLaren A 1995 Germ cells and germ cell sex. Philosophical Transactions of the Royal Society of London. Series B, Biological Sciences 350 229-233. (doi:10.1098/rstb.1995.0156)

McLaren A 2003 Primordial germ cells in the mouse. Developmental Biology 262 1-15. (doi:10.1016/S0012-1606(03)00214-8)

Merchant H 1975 Rat gonadal and ovarian organogenesis with and without germ cells. An ultrastructural study. Developmental Biology 44 1-21. (doi:10.1016/0012-1606(75)90372-3)

Merchant-Larios H \& Centeno B 1981 Morphogenesis of the ovary from the sterile W/Wv mouse. Progress in Clinical and Biological Research 59B 383-392.

Moniot B, Ujjan S, Champagne J, Hirai H, Aritake K, Nagata K, Dubois E, Nidelet S, Nakamura M, Urade Y et al. 2014 Prostaglandin D2 acts through the Dp2 receptor to influence male germ cell differentiation in the foetal mouse testis. Development 141 3561-3571. (doi:10.1242/dev. 103408)

Morinaga C, Saito D, Nakamura S, Sasaki T, Asakawa S, Shimizu N, Mitani H, Furutani-Seiki M, Tanaka M \& Kondoh H 2007 The hotei mutation of medaka in the anti-Müllerian hormone receptor causes the dysregulation of germ cell and sexual development. PNAS 104 9691-9696. (doi:10.1073/pnas.0611379104)

Nagamine CM \& Carlisle C 1996 The dominant white spotting oncogene allele Kit(W-42J) exacerbates XY(DOM) sex reversal. Development 122 3597-3605.

Nagamine CM, Capehart J, Carlisle C \& Chang D 1998 Ovotestes in B6-XXSxr sex-reversed mice. Developmental Biology 196 24-32. (doi:10.1006/dbio.1997.8826)

Nakamura S, Watakabe I, Nishimura T, Picard JY, Toyoda A, Taniguchi Y, di Clemente N \& Tanaka M 2012 Hyperproliferation of mitotically active germ cells due to defective anti-Müllerian hormone signaling mediates sex reversal in medaka. Development 139 2283-2287. (doi:10.1242/dev.076307)

Nekola MV \& Nalbandov AV 1971 Morphological changes of rat follicular cells as influenced by oocytes. Biology of Reproduction 4 154-160.

O'Shaughnessy PJ, Hu L \& Baker PJ 2008 Effect of germ cell depletion on levels of specific mRNA transcripts in mouse Sertoli cells and Leydig cells. Reproduction 135 839-850. (doi:10.1530/REP-08-0012)

Piprek RP, Pecio A, Kubiak JZ \& Szymura JM2012 Differential effects of busulfan on gonadal development in five divergent anuran species. Reproductive Toxicology 34 393-401. (doi:10.1016/j.reprotox.2012.05.002)

Regenass U, Friedrich TD \& Stevens LC 1982 Experimental induction of testicular teratomas in dissociated-reaggregated chimaeric gonads. Journal of Embryology and Experimental Morphology 72 153-167.

Rodriguez-Mari A, Canestro C, Bremiller RA, Nguyen-Johnson A, Asakawa K, Kawakami K \& Postlethwait JH 2010 Sex reversal in zebrafish fancl mutants is caused by Tp53-mediated germ cell apoptosis. PLoS Genetics 6 e1001034. (doi:10.1371/journal.pgen.1001034)

Ross AJ \& Capel B 2005 Signaling at the crossroads of gonad development. Trends in Endocrinology and Metabolism 16 19-25. (doi:10.1016/j.tem. 2004.11.004)

Sekido R \& Lovell-Badge R 2008 Sex determination involves synergistic action of SRY and SF1 on a specific Sox9 enhancer. Nature 453 930-934. (doi:10.1038/nature06944)

Siegfried KR \& Nusslein-Volhard C 2008 Germ line control of female sex determination in zebrafish. Developmental Biology 324 277-287. (doi:10.1016/j.ydbio.2008.09.025)

Slanchev K, Stebler J, de la Cueva-Mendez G \& Raz E 2005 Development without germ cells: the role of the germ line in zebrafish sex differentiation. PNAS 102 4074-4079. (doi:10.1073/pnas.0407475102)

Soyal SM, Amleh A \& Dean J 2000 FIGalpha, a germ cell-specific transcription factor required for ovarian follicle formation. Development 127 4645-4654.

Spiller CM, Feng CW, Jackson A, Gillis AJ, Rolland AD, Looijenga LH, Koopman P \& Bowles J 2012 Endogenous Nodal signaling regulates germ cell potency during mammalian testis development. Development 139 4123-4132. (doi:10.1242/dev.083006) 
Svingen T \& Koopman P 2013 Building the mammalian testis: origins, differentiation, and assembly of the component cell populations. Genes and Development 27 2409-2426. (doi:10.1101/gad.228080.113)

Syed V, Gomez E \& Hecht NB 1999 Messenger ribonucleic acids encoding a serotonin receptor and a novel gene are induced in Sertoli cells by a secreted factor(s) from male rat meiotic germ cells. Endocrinology 140 5754-5760.

Taketo-Hosotani T, Merchant-Larios H, Thau RB \& Koide SS 1985 Testicular cell differentiation in fetal mouse ovaries following transplantation into adult male mice. Journal of Experimental Zoology 236 229-237. (doi:10.1002/jez.1402360213)

Uhlenhaut NH, Jakob S, Anlag K, Eisenberger T, Sekido R, Kress J, Treier AC, Klugmann C, Klasen C, Holter NI et al. 2009 Somatic sex reprogramming of adult ovaries to testes by FOXL2 ablation. Cell 139 1130-1142. (doi:10.1016/j.cell.2009.11.021)

Ungewitter EK \& Yao HH 2013 How to make a gonad: cellular mechanisms governing formation of the testes and ovaries. Sexual Development 7 7-20. (doi:10.1159/000338612)

Vanderhyden BC \& Macdonald EA 1998 Mouse oocytes regulate granulosa cell steroidogenesis throughout follicular development. Biology of Reproduction 59 1296-1301. (doi:10.1095/biolreprod59.6.1296)

Vanderhyden BC, Telfer EE \& Eppig JJ 1992 Mouse oocytes promote proliferation of granulosa cells from preantral and antral follicles in vitro. Biology of Reproduction 461196-1204. (doi:10.1095/biolreprod46.6.1196)
Vanderhyden BC, Cohen JN \& Morley P 1993 Mouse oocytes regulate granulosa cell steroidogenesis. Endocrinology 133 423-426. (doi:10. 1210/endo.133.1.8319589)

Vigier B, Watrin F, Magre S, Tran D \& Josso N 1987 Purified bovine AMH induces a characteristic freemartin effect in fetal rat prospective ovaries exposed to it in vitro. Development $10043-55$.

Weidinger G, Stebler J, Slanchev K, Dumstrei K, Wise C, Lovell-Badge R, Thisse C, Thisse B \& $\mathbf{R a z}$ E 2003 dead end, a novel vertebrate germ plasm component, is required for zebrafish primordial germ cell migration and survival. Current Biology 13 1429-1434. (doi:10.1016/S09609822(03)00537-2)

Wilhelm D, Martinson F, Bradford S, Wilson MJ, Combes AN, Beverdam A, Bowles J, Mizusaki H \& Koopman P 2005 Sertoli cell differentiation is induced both cell-autonomously and through prostaglandin signaling during mammalian sex determination. Developmental Biology 287 111-124. (doi:10.1016/j.ydbio.2005.08.039)

Received 18 December 2014

First decision 12 January 2015

Revised manuscript received 18 January 2015

Accepted 27 January 2015 